ROSE LOUISE GOSS

\title{
A DECAY OF RIGHTS: THE DECISION IN NEW HEALTH NEW ZEALAND INC V SOUTH TARANAKI DISTRICT COUNCIL
}

Submitted for the LLB (Honours) Degree

Faculty of Law

Victoria University of Wellington

2014 


\begin{abstract}
The decision in New Health New Zealand Inc v South Taranaki District Council is the most recent legal development in the New Zealand debate about fluoridation of public water supplies. That decision centred on the interpretation of section 11 of the New Zealand Bill of Rights Act, the right to refuse medical treatment. The Court held that the fluoridation in question was legal, and reached a limited definition of medical treatment that did not encompass fluoridation. This paper analyses the reasoning leading to that interpretation, concluding that the decision is problematic and that the definition of s 11 needs to be remedied. The use of the wording of $s 11$ to limit the definition of medical treatment was inappropriate, as was the policy reasoning used to support that limitation. The structure of reasoning followed exacerbated these issues and adhered too closely to the reasoning in United States cases. Furthermore, the application of a de minimis threshold was conducted without adequate scrutiny, and such a threshold should not be applied to s 11 .
\end{abstract}

Key words: New Zealand Bill of Rights, fluoridation, right to refuse medical treatment, New Health New Zealand Inc v South Taranaki District Council. 


\section{Table of Contents}

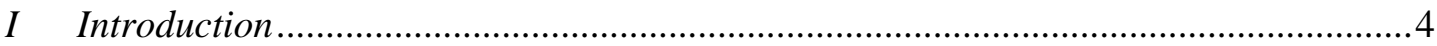

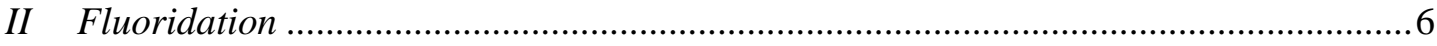

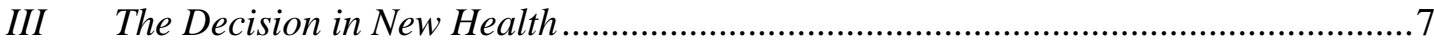

IV Analysis of the Interpretation of Section 11 in New Health ......................................9

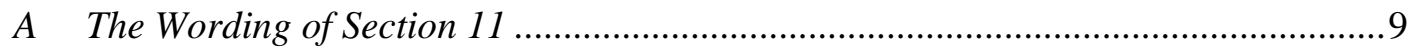

B Policy Reasoning in New Health ..................................................................... 11

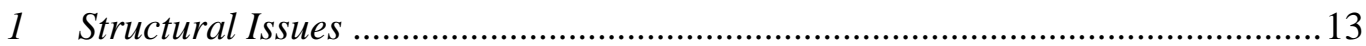

2 The New Zealand Framework........................................................................ 15

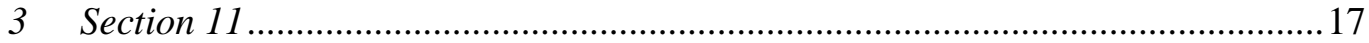

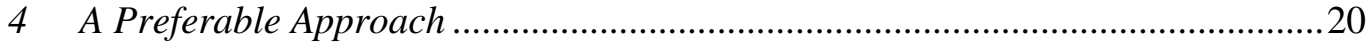

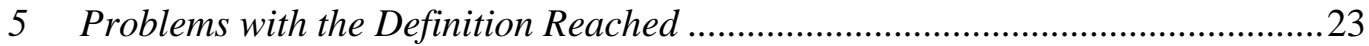

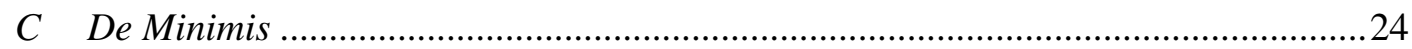

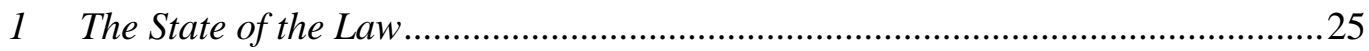

2 Relevance of De Minimis to Section 11 ...........................................................26

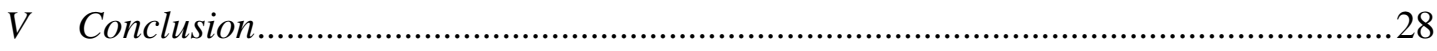

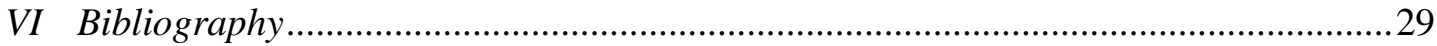

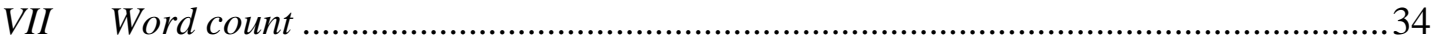




\section{Introduction}

In Texas and Colorado in the 1900s, a peculiar phenomenon of stained teeth became noticeable and was referred to as both "Texas Teeth" and "Colorado Brown Stain". Investigations soon revealed that the stained teeth, while unsightly, were also more resistant to dental caries. ${ }^{2}$ Further analysis revealed that the cause of both the resistance and the staining was fluoride, and the benefits of fluoride were soon acknowledged by public health authorities and fluoride was added to public water supplies. ${ }^{3}$ Fluoride has since become a common additive to water supplies worldwide. ${ }^{4}$ Despite this, its presence is controversial and has incited opposition and spawned numerous legal challenges. ${ }^{5}$ As of yet, these challenges have not been successful. ${ }^{6}$

A different weapon in the arsenal of anti-fluoride campaigners in New Zealand has recently been tested: section 11 of the New Zealand Bill of Rights Act (BORA), the right to refuse medical treatment. The first attempt to contest fluoridation on the basis of this right occurred in 2013, in New Health New Zealand Inc v South Taranaki District Council (New Health). ${ }^{7}$ This case note intends to analyse the part of that decision regarding the interpretation of $s$ 11 , and limitation of medical treatment.

The definition of s 11 that was formulated in New Health is particularly important, as it is key to the controversy surrounding fluoride. This paper posits that the reasoning in New Health is flawed, and led to the incorrect conclusion that fluoridation is not medical treatment for the purposes of s 11. It is possible that this may be remedied by a future court, ${ }^{8}$ and that fluoridation could constitute a prima facie breach of s 11 . This would in turn mean that the section 5 analysis, as to whether a breach of a right is reasonably and demonstrably justified, ${ }^{9}$ would receive greater focus. Such an analysis would better accommodate

\footnotetext{
${ }^{1}$ Eugene Garfield “Fluoridation, ‘Texas Teeth’, and the Great Conspiracy” (1986) 9 Essays of An Information Scientist 3 at 3.

2 Jill Wrapson “Artificial Fluoridation of Public Water Supplies in New Zealand: Magic Bullet, Rat Poison, or Communist Plot?” (2005) 7 Health and History 17 at 19.

${ }^{3}$ At 19.

${ }^{4}$ Robert E Clark and Michael M Sophy “Fluoridation: The Courts and Opposition” (1967) 13 Wanye Law Rev 338 at 338.

${ }^{5}$ At 342 .

${ }^{6}$ At 375.

${ }^{7}$ New Health New Zealand Inc v South Taranaki District Council [2014] NZHC 395.

${ }^{8}$ See New Zealand Herald "Fight to Remove Fluoride Taken to the Court of Appeal” (26 March 2014)

$<$ www.nzherald.co.nz>.

${ }^{9}$ New Zealand Bill of Rights Act 1990, s 5.
} 
discussion of new research developments in this area, ${ }^{10}$ meaning that those developments could have a greater impact on the legality of fluoridation.

Thus far, there has been a lack of current and reliable research undertaken in regard to the safety of fluoridation. The most comprehensive recent report is the York Review on Water Fluoridation (2000), ${ }^{11}$ which was itself critical of the amount of evidence available about fluoridation. ${ }^{12}$ Closer to home, the Royal Society of New Zealand has undertaken a review of the available scientific research on the safety and efficacy of fluoride. ${ }^{13}$ The report concluded that community water fluoridation provides dental benefits, and does not pose a risk to public health. ${ }^{14}$ Nevertheless, new scientific developments may emerge and change the nature of this debate. The role of future research will depend very much on whether the reasoning in New Health is followed in subsequent cases, or whether its flaws are recognised and corrected. It is thus imperative to explore the interpretation of New Health and to highlight the defects of the decision, as the definition of s 11 remains central to the legal landscape surrounding the fluoridation debate.

This paper intends to establish that a combination of erroneous reasoning led to the incorrect conclusion that fluoridation does not constitute medical treatment. Initially, the paper will provide a background of fluoridation and the debate surrounding it. The paper then summarises the reasoning and result in New Health. It should be noted the scope of this paper is limited and will not involve an extensive discussion of the issues in the case that are not connected with s 11, as the scope of s 11 is the issue most in need of rectification.

Part IV analyses three main points of the reasoning in New Health. First, the wording of s 11 was improperly interpreted and does not require a limitation of medical treatment. Second, the policy analysis used to support a limited definition of s 11 is out of place at the

\footnotetext{
${ }^{10}$ See Part IV B 4.

${ }^{11}$ Matthew Bradley and others A Systematic Review of Public Water Fluoridation (NHS Centre for Reviews and Dissemination, Report 18, September 2000); and ET Treasure and others "The York Review - A Systematic Review of Public Water Fluoridation: A Commentary” (2002) 192 British Dental Journal 495 at 495. For information on the most recent New Zealand study of fluoridation, see University of Otago “Fluoridating Water Does Not Lower IQ: Otago Research” (19 May 2014) <www.otago.ac.nz>.

12 Treasure and others, above n 11, at 497. For another recent scientific discussion of fluoride, see Phillip Grandjean and Phillip Landrigan “Neurobehavioural effects of developmental toxicity” (2014) 13 The Lancet Neurology 330.

${ }^{13}$ Office of the Prime Minister's Chief Science Advisor and the Royal Society of New Zealand Health Effects of Water Fluoridation: a Review of the Scientific Evidence (August 2014).

${ }^{14}$ At 56.
} 
definitional stage of reasoning and should instead have been left to a s 5 analysis; a limitation is not in accordance with the purpose of s 11. This policy reasoning is based on misplaced concerns about the ability of an individual to veto a public health measure, leading to a definition with problematic ramifications. The paper will assert that a preferable approach would involve a wide interpretation of medical treatment which would include fluoridation. The third main issue of reasoning is that the application of the de minimis approach is skirted over too briefly in New Health, and analysis reveals that it should not have been applied to s 11.

Overall, this paper endeavours to elucidate the shortcomings of the interpretation of s 11 in New Health, and to suggest a more desirable approach.

\section{Fluoridation}

Currently, around 50 percent of New Zealanders drink fluoridated water, ${ }^{15}$ a practice which the Ministry of Health refers to as a "safe, effective and affordable way to prevent and reduce tooth decay across the whole population." 16 While common, fluoridation remains controversial. The growing opposition to fluoridation in New Zealand has included campaigns from groups such as the Fluoride Action Network New Zealand and New Health New Zealand Incorporated (New Health). These groups challenge the effectiveness of, and highlight alleged dangers of, fluoridation. ${ }^{17}$ One accepted side effect of fluoridation is fluorosis (an aesthetic "defect of the tooth enamel”), ${ }^{18}$ but less commonly discussed side effects are also alleged, such as arthritis and even heart disease. ${ }^{19}$

Overseas, similar opposition is apparent, due to the fact that fluoridation is closely linked to widely held ideas, such as fear of toxic chemicals and distrust of governmental intrusions into personal freedoms. ${ }^{20}$ This opposition has led to legal challenges, ${ }^{21}$ focusing on whether

\footnotetext{
${ }^{15}$ Ministry of Health "Fluoride” (20 September 2013) <www.health.govt.nz>.

${ }^{16}$ Ministry of Health "Fluoridation" (5 February 2014) <www.health.govt.nz $>$.

${ }^{17}$ See Fluoride Action Network NZ Inc "Fluoride Free New Zealand” <http://fluoridefree.org.nz>; and New Health NZ "News" < www.newhealth.co.nz>.

${ }^{18}$ Ministry of Health "Fluoride and Health" (30 August 2011) <www.health.govt.nz>.

${ }^{19}$ Fluoride Action Network NZ Inc "Fluoridation and Heart Disease” and "FAQ” < http://fluoridefree.org.nz>.

${ }^{20}$ Brian W Head “The Fluoridation Controversy in Victoria: Public Policy and Group Politics (1978) 37

AJPA 257 at 258.

${ }^{21}$ See for example Millership v British Columbia [2003] BCSC 82; Dowell v City of Tulsa 273 P 2d 859 (1954); and Kraus v City of Cleveland 127 NE 2s 779 (1995).
} 
certain bodies have the power to fluoridate, and also on arguments attacking fluoridation as breaching particular rights. ${ }^{22}$ Different legal frameworks overseas mean these challenges have often relied on broadly stated rights, such as s 7 of the Canadian Charter of Rights and Freedoms which protects liberty and security of the person. ${ }^{23}$ Such challenges have thus far been largely unsuccessful. ${ }^{24}$

The lack of successful litigation overseas has likely been a deterrent to similar action in New Zealand. Another deterrent may have been a New Zealand Human Rights Commission report in 1980, which concluded that fluoridation was not a denial of human rights. ${ }^{25}$ Nevertheless, another option has now been tested. Enacted in 1990, s 11 of BORA provides a right to refuse medical treatment. The right is unique as it is particularly specific and has no direct international equivalent. ${ }^{26}$ Section 11 therefore allows a slightly different type of challenge in comparison to those undertaken overseas. The decision in New Health involved the first discussion in a court about the legality of fluoridation in relation to s 11 .

\section{The Decision in New Health}

In 2012, the South Taranaki District Council (the Council) made the decision to fluoridate the water supplies of Patea and Wavereley, in South Taranaki. This decision was challenged by New Health, by way of judicial review. ${ }^{27}$

Section 11 of BORA was central to the arguments and decision in New Health. Section 11 states that "everyone has the right to refuse to undergo any medical treatment", ${ }^{28}$ and is part of a group of rights which "recognise the right to dignity and security of the person". ${ }^{29}$ The right has been interpreted broadly, and held to cover instances such as psychological testing

\footnotetext{
${ }^{22}$ Clark and Sophy, above n 4 at, 342.

${ }^{23}$ Canadian Charter of Rights and Freedoms, s 7. See also the European Convention on Human Rights, art 8; the Florida Constitution, art 1 s 23; the United States Constitution, amendment 14; and the Irish Constitution Act, art 40.3.

${ }^{24}$ Clark and Sophy, above n 4, at 375.

${ }^{25}$ New Zealand Human Rights Commission Report on Representations on Fluoridation of Water Supplies (1980).

${ }^{26}$ Paul Rishworth and others The New Zealand Bill of Rights (Oxford University Press, Melbourne, 2003) at 252.

${ }^{27}$ See New Health New Zealand Inc v South Taranaki District Council, above n 7, at [2].

${ }^{28}$ New Zealand Bill of Rights Act 1990, s 11.

${ }^{29}$ See New Zealand Bill of Rights Act, ss 8, 9, 10, 11. See also A Butler and P Butler The New Zealand Bill of Rights Act: A Commentary (Lexis Nexis, Wellington, 2005) at 11.6.1.
} 
with a therapeutic purpose, and a medical examination of children relating to their health and safety. ${ }^{30}$ As anticipated by the White Paper, ${ }^{31}$ the majority of issues that have arisen thus far in relation to s 11 have regarded the nature of consent required by the section. ${ }^{32}$ In contrast, New Health focused on the interpretation of medical treatment.

While New Health did challenge the Council's power to fluoridate, ${ }^{33}$ this argument was not successful as the High Court held that the Council had a "clear legislative mandate" to add fluoride to drinking water supplies. ${ }^{34}$ The bulk of the case involved discussion of the legality of fluoridation in relation to BORA, with New Health alleging that the fluoridation of public water supplies was a breach of s 11 that was not prescribed by law and that was an unjustified and disproportionate limit on s $11 .{ }^{35}$ Hansen J's reasoning in this area will be elaborated on below, but his Honour concluded that fluoridation is not medical treatment and therefore does not fall within the scope of s $11 .{ }^{36} \mathrm{New}$ Health also raised a number of arguments about the Council's decision making process, arguing that the Council failed to take into account a series of mandatory relevant considerations. ${ }^{37}$ However, the majority of these considerations related to the alleged breach of BORA, ${ }^{38}$ and these arguments were therefore not successful. Overall, this cause of action also failed. ${ }^{39}$

New Health was unsuccessful in regard to each argument raised. Their applications for declarations regarding the decision being both ultra vires and in breach of BORA, and a further application for an order quashing the decision, all failed. ${ }^{40}$

\footnotetext{
${ }^{30}$ See M v Attorney General [2006] NZFLR 181; and Smith v Attorney General HC Wellington CIV-2005485-1785, 9 July 2008 at [100].

${ }^{31}$ Geoffrey Palmer “A Bill of Rights for New Zealand: A White Paper” [1984-1985] I AJHR A6 at 109.

${ }^{32}$ Butler and Butler, above n 29, at 11.9. See for example, Re E [1993] 1 FLR 386; and Re S [1992] 1 NZLR 363 (HC).

${ }^{33}$ New Health New Zealand Inc v South Taranaki District Council, above n 7, at [2].

${ }^{34}$ At [37].

${ }^{35}$ At [2].

${ }^{36}$ At [90].

${ }^{37}$ At [2].

${ }^{38}$ At [112].

${ }^{39}$ At [114].

${ }^{40}$ At [13] and [121].
} 


\section{Analysis of the Interpretation of Section 11 in New Health}

Certain aspects of the above reasoning require a more detailed analysis. This Part will undertake an analysis of the way that the wording of s 11 was used to limit the section, the policy considerations used to support that limitation, and, the application of a de minimis approach.

\section{A The Wording of Section 11}

When using the wording of s 11 to determine the scope of medical treatment, Hansen $\mathrm{J}$ acknowledged that the purpose of an intervention is relevant to whether it is medical treatment. ${ }^{41}$ In order for something to be medical treatment, it must have a therapeutic purpose. ${ }^{42}$ Hansen $\mathrm{J}$ concluded that fluoridation clearly has a therapeutic objective as it is "a process undertaken for the purpose of preventing or arresting a disease”: dental caries. ${ }^{43}$ Despite this, his Honour held that the wording of s 11 meant something more than just a therapeutic purpose was required, and that s 11 can only apply to the treatment of an individual, as opposed to treatment administered to groups. ${ }^{44}$ This conclusion was reached after Hansen J found that "the terms of s 11 themselves indicate that medical treatment is of a more limited scope". ${ }^{45}$ Section 11 protects a right to refuse to "undergo" medical treatment without consent, and Hansen $\mathrm{J}$ asserted that the word 'undergoing' cannot be applied comfortably to the process of drinking fluoridated water and, further, that fluoridation is more likely to be described as something that is 'done' to a patient. ${ }^{46}$

Hansen $\mathrm{J}$ also compared the wording in s 11 with that in ss 9 and 10 of BORA, ${ }^{47}$ which protect rights not to be subjected to torture or cruel treatment and not to be subjected to either medical or scientific experimentation respectively ${ }^{48}$ His Honour concluded that the

\footnotetext{
${ }^{41}$ At [55].

42 At [55] and [57]. See also Butler and Butler, above n 29, at 11.8.5. To compare with the Australian and European approaches see Douglas Cross "Water Fluoridation as Mass Medication" (7 April 2013) $<$ www.xproexperts.co.uk> at 3.

${ }^{43}$ At [58] and [79].

${ }^{44}$ At [84].

${ }^{45}$ At [82].

${ }^{46}$ At [82].

${ }^{47}$ At [83].

${ }^{48}$ New Zealand Bill of Rights Act 1990, ss 9 and 10.
} 
inclusion of "subject to" in ss 9 and 10 means that those rights cover a broader range of activities, while s 11 has a narrower scope due to the use of "undergo". 49

This reasoning led Hansen $\mathrm{J}$ to the preliminary conclusion that "the right to refuse medical treatment is only engaged when the treatment takes place in the context of a therapeutic relationship in which medical services are provided to an individual."50

The Court was wrong to reach this conclusion, as the wording of s 11 does not clearly require a limitation. Firstly, the difference in wording between ss 9 and 10, and s 11, may be due to the divergent nature of these rights. Torture and scientific or medical experimentation are quite different concepts to medical treatment, and it is logical that the verbs used in regard to them are different to those used in relation to medical treatment. The Oxford Dictionary defines 'subject' as: “... to cause or force someone or something to undergo ... a particular experience or form of treatment, typically an unwelcome or unpleasant one". ${ }^{1}$ This emphasises that 'subject to' is likely to be used in regard to especially negative situations. The concepts in ss 9 and 10 have more obviously negative connotations than s 11, supported by the fact that s 10 is based on art 7 of the International Covenant on Civil and Political Rights (ICCPR), ${ }^{52}$ which protects people from torture and cruel treatment and was "a response to the atrocities of Nazi concentration camps". ${ }^{33}$

Secondly, the difference in wording may also be due to the way the activities relevant to the different rights would be conducted. Sections 9 and 10 use "subject to", envisaging activities that would be forced upon people. The use of "undergo" in s 11 is a more appropriate word for $\mathrm{s} 11$, which is intended to apply to treatment that is optionally undertaken. Medical treatment with consent, envisaged by s 11, is benign and is not likely to be something people are 'subjected to'.

These alternate explanations reach the opposite conclusion to Hansen J, indicating that ss 9 and 10 may in fact be of a narrower scope than s 11 .

\footnotetext{
${ }^{49}$ At [83].

${ }^{50}$ At [84].

${ }^{51}$ Oxford Dictionaries "Subject" < www.oxforddictionaries.com>.

52 International Covenant on Civil and Political Rights 999 UNTS 171 (opened for signature 16 December 1966, entered into force 23 March 1976), art 7. See Butler and Butler, above n 29, at 11.4.2.

53 Manfred Nowak UN Covenant on Civil and Political Rights: CCPR Commentary (2 ${ }^{\text {nd }}$ ed NP Engel Publishing, Kehl, 2005) at 188.
} 
Another available counter argument to the Court's reasoning is that if Parliament only wanted this right to apply to treatment of an individual, a limitation could have been expressed in the wording of the section. The absence of such wording implies that rights can be applied both to conduct towards individuals, and to conduct applied to groups. Further, neither s 10 of BORA nor art 7 of the ICCPR specify that they are intended to apply to groups of people, but this is clearly the case, considering the history of the sections, ${ }^{54}$ as a number of Nazi concentration camps conducted experiments involving treatment being administered to groups of people simultaneously. ${ }^{55}$ Logically it should be presumed that the right in s 10 applies to similar situations, rather than just to treatment and experimentation administered to individuals. Therefore, the fact that a right does not specifically state that it covers administration of treatment to a group of individuals does not necessarily mean such an application would be outside the ambit of the right's protection.

The wording of s 11 does not, on its own, stipulate that the scope of medical treatment should be limited to direct treatment of individuals.

\section{B Policy Reasoning in New Health}

Hansen $\mathrm{J}$ concluded that the policy implications relevant to limiting the scope of medical treatment supported a restrictive reading of $\mathrm{s} 11 .{ }^{56}$ This reasoning is flawed as it overestimates the ability of individuals to veto public health measures. Further, Hansen $\mathrm{J}$ mimics the approach of United States authorities, resulting in a structure of reasoning that is not appropriate in the New Zealand context and that does not adequately reflect the purpose of s 11 . These factors lead to a definition that has problematic implications.

A pivotal point in this section of reasoning was that s 11 should be limited to the direct treatment of an individual, as "within that sphere there are no competing interests that need to be moderated or resolved." ${ }^{57}$ Hansen J argued that the right should not be engaged where

\footnotetext{
54 See Butler and Butler, above $n$ 29, at 11.4.2.

55 Telford Taylor “Opening Statement of the Prosecution, December 9, 1946” in George J Annas and Michael A Grodin (eds) The Nazi Doctors and the Nuremburg Code; Human Rights in Human Experimentation (Oxford University Press, New York, 1992) at 75, 77, and 83.

${ }^{56}$ New Health New Zealand Inc v South Taranaki District Council, above n 7, at [86]-[90].

${ }^{57}$ At [86].
} 
the state employs public health interventions, because "were it otherwise, the individual's right to refuse would become the individual's right to decide outcomes for others." 58 In sum, Hansen $\mathrm{J}$ considered that s 11 should be limited to direct treatment of an individual, as if that were not the case, an individual proving a breach of $\mathrm{s} 11$ in relation to a public health measure could stop implementation of that measure. The Court concluded that s 11 is not engaged where the state employs public health interventions, ${ }^{59}$ and that therefore fluoridation is not medical treatment. ${ }^{60}$

Hansen J's policy concerns are overstated, as many public health measures will not lead to the possibility of a breach of s 11 and will not give an individual the chance to veto a public health measure. In order to breach s 11 , the public health measure must be of a nature that is not practical to refuse. ${ }^{61}$ Regarding fluoridation, Hansen $\mathrm{J}$ logically concluded that an individual would not have the practical ability to refuse fluoridated water, ${ }^{62}$ as they could not reasonably avoid something in their water supply ${ }^{63}$ Following that reasoning in New Health, anything included in a public water supply is likely to meet the threshold of being impractical to refuse, ${ }^{64}$ as is any legislative scheme providing for compulsory treatment. ${ }^{65}$ However, the pervasiveness of fluoridation can be linked to the fact that extensive measures must be used to combat dental caries, as it is such a widespread issue. ${ }^{66}$ Many public health measures will not be so extensive and will not be impractical to refuse.

For example, Hansen $\mathrm{J}$ asserted that the addition of folic acid to bread is comparable to fluoridation, and that as a public health measure it would not constitute medical treatment. ${ }^{67}$ This is not an appropriate comparison, as the current use of folic acid in New Zealand is an example of a public health measure that can easily be avoided. Folic acid is added to some

\footnotetext{
${ }^{58}$ At [86].

${ }^{59}$ At [86].

${ }^{60}$ At [91].

${ }^{61}$ At [91].

${ }^{62}$ At [94].

63 At [94].

${ }^{64}$ At [80] and [94].

${ }^{65}$ For an example of such a scheme, see Jacobson v Commonwealth of Massachusetts 197 US 11, 25 S Ct 358 (1905).

${ }^{66}$ Abel Wolman, JC Geiger and WC Morse "Should Public Water Supplies be used for Mass Medication" (1947) 39 American Water Works Association 834 at 863. See also GA Strong "Liberty, Religion and Fluoridation” (1967) 8 Santa Clara Lawyer 37 at 44.

${ }^{67}$ At [81].
} 
types of bread, ${ }^{68}$ to reduce the risk of neural tube defects in babies. ${ }^{69}$ While the Ministry for Primary Industries has set guidelines about the amounts to be added, addition of folic acid is voluntary and it is not added to all types of bread. ${ }^{70}$ Therefore, those who do not wish to consume additional folic acid can easily avoid doing so. This measure is unlikely to cause a breach of s 11, and is not on par with fluoridation as it does not raise the possibility of an individual being able to veto a public health measure. Along with other public health measures, such as free influenza vaccinations for people in certain age and health brackets, ${ }^{71}$ the fortification of bread with folic acid can be practically avoided. These examples do not support Hansen J's finding that all public health measures should be excluded from s 11, as an individual would have no power to veto their implementation.

Another flaw of the policy reasoning in New Health is that it implicitly assumes that, if fluoridation or another public health measure were to be considered medical treatment, the implementation of such a measure would be an unjustifiable breach of the right to refuse medical treatment. Hansen $\mathrm{J}$ neglects to outline that a breach of s 11 could be justifiable under s 5, which states that BORA rights "may be subject only to such reasonable limits prescribed by law as can be demonstrably justified in a free and democratic society", ${ }^{72}$ Section 5 means that BORA rights can be subject to reasonable limits. If fluoridation was held to be a reasonable limit on s 11, an individual would not be able to prevent or stop it, as $\mathrm{s} 5$ would prevent them from establishing a breach. The failure to explain this further undermines the reasoning in this section.

\section{$1 \quad$ Structural Issues}

Hansen J's use of policy concerns to limit the definition of s 11 is also problematic, as those concerns should instead have been discussed under a s 5 analysis.

The structure Hansen $\mathrm{J}$ follows is reminiscent of the approach taken in the United States cases relating to this issue. ${ }^{73}$ In some instances, examination of relevant policy concerns can

\footnotetext{
${ }^{68}$ For a list of fortified breads (as at 2011) see Ministry for Primary "Folic Acid Fortified Breads” (2011) $<$ www.foodsmart.govt.nz $>$.

${ }^{69}$ Ministry of Health "Folate/Folic Acid” (October 2013) <www.health.govt.nz>.

${ }^{70}$ Ministry for Primary Industries “Fortification of Bread with Folic Acid Q\&A” (October 2012) $<$ www.foodsafety.govt.nz>.

${ }^{71}$ National Influenza Specialist Group “Can I get a Free Flu Vaccine” <www.fightflu.co.nz>.

72 New Zealand Bill of Rights Act 1990, s 5.

${ }^{73}$ See for example - the US cases that I think use definitional balancing
} 
lead to the limitation of the definition of a right. For example, in a United States case, Kraus $v$ City of Cleveland, ${ }^{74}$ a case about the legality of fluoridation, a definitional limitation was read in to the fundamental liberties protected by the United States Constitution. Justice Matthias considered policy implications, and limited the right because: ${ }^{75}$

The liberty secured by the constitution of the United States to every person within its jurisdiction does not import an absolute right in each person ... There are manifold restraints to which every person is necessarily subject for the common good.

This approach is referred to as definitional balancing, "meaning that matters of evaluation are built into a definition of the right concerned." ${ }^{\text {"6 }}$ Definitional balancing is applied in the United States, and is also apparent in New Health, when Hansen J uses policy considerations to determine the scope of s 11 . As outlined, one such consideration in New Health focused on what would allow the greatest good for the greatest number. ${ }^{77}$ This argument is apparent in United States cases involving human rights related challenges to the legality of public health measures. ${ }^{78}$ For example, in Dowell v City of Tulsa, the fact that a right to refuse fluoridation would not be in the interests of the community as a whole meant that the challenge to the legality of fluoridation failed. ${ }^{79}$ In Jacobson $v$ Commonwealth of Massachusetts, Justice Harlan stated that if a man were able to refuse a compulsory smallpox vaccination, "the spectacle would be presented of the welfare and safety of an entire population being subordinated to the notions of a single individual". ${ }^{80}$ Hansen $\mathrm{J}$ does not specifically reference Jacobson in the context of his policy considerations, but is clearly following a very similar line of reasoning when he indicates concern about the possibility of an individual being able to veto public health measures.

\footnotetext{
${ }^{74}$ Kraus v City of Cleveland, above n 21.

${ }^{75}$ At 801.

${ }^{76}$ Rishworth and others, above n 26, at 53.

${ }^{77}$ At [86].

${ }^{78}$ See for example Dowell $v$ City of Tulsa, above n 21, Minnesota State Board of Health $v$ City of Brainerd 241 NW 2d 624 (1976) at 632, and Jacobson v Commonwealth of Massachusetts, above n 65 at 336.

${ }^{79}$ Dowell v City of Tulsa, above n 21, at 863. See also Minnesota State Board of Health v City of Brainerd, above $\mathrm{n} 78$ at 632.

80 Jacobson v Commonwealth of Massachusetts, above n 65, at 336.
} 
The Court should not have adhered to the United States approaches, as the New Zealand courts have only applied definitional balancing in restricted circumstances. ${ }^{81}$ In $R e J$, the Court of Appeal held that, in an instance where BORA rights conflicted, ${ }^{82}$ definitional balancing was appropriate to ensure the effective compatibility of the rights in question. However, even this narrow use of definitional balancing has been controversial. ${ }^{83}$

The presence of s 5, a limitation clause, means that definitional balancing should not automatically be applied in New Zealand. To reiterate, s 5 means that a measure can legally limit a right, if the measure is prescribed by law and reasonably and demonstrably justified. ${ }^{84}$ In contrast, the United States has no limitation clause, meaning that courts must read in limitations at the definitional stage by assessing all relevant policy arguments. ${ }^{85}$ For example, the point Hansen $\mathrm{J}$ relies on from Dowell is about the fact that the protection of liberty does not require "immunity from reasonable regulations imposed in the interests of the community". ${ }^{86}$ This focus on reasonableness in Dowell is an example of the American Court performing something close to a s 5 analysis when defining the Fourteenth Amendment, which is much more broadly phrased than s $11 .{ }^{87}$ This is further evidence that this type of discussion could be completed at a further stage of the BORA analysis, and that Hansen $\mathrm{J}$ is following the United States approach too closely. In some circumstances, ${ }^{88}$ it is appropriate to read in a limit when a right is defined, but not unless this is in accordance with the purpose of the relevant right. The presence of s 5 creates a unique New Zealand framework and means it cannot be assumed that limitations at a definitional stage are appropriate.

\section{The New Zealand Framework}

In $R v B$, when comparing the New Zealand and United States rights protection frameworks, Richardson J noted that: ${ }^{89}$

\footnotetext{
${ }^{81}$ See Re J (An Infant): B and B v Director-General of Social Welfare [1996] 2 NZLR 134 (CA).

${ }^{82}$ At 146.

${ }^{83}$ Rishworth and others, above n 26 at 55; and Butler and Butler, above n 29 at 6.6.17.

${ }^{84}$ New Zealand Bill of Rights Act 1990, s5.

${ }^{85}$ Butler and Butler, above n 29, at 6.6.2.

${ }^{86}$ Dowell $v$ City of Tulsa, above n 21, at 863, emphasis added. See New Health New Zealand Inc $v$ South Taranaki District Council, above n 7, at 76.

${ }^{87}$ United States Constitution, amendment 14.

${ }^{88}$ See Part IV B 2.

${ }^{89} R v B$ [1995] 2 NZLR 172 (CA) at 183.
} 
... The American Bill of Rights does not contain a limitation clause and, since rights cannot be absolute, the American courts have had to imply qualifications on absolute rights ... In New Zealand s 5 is the statutorily mandated test ... It requires the New Zealand courts to develop their own pattern of reasoning in a case such as the present.

The presence of the limitation clause in BORA means limitation should be less likely to occur when a right is defined. Instead, considerations of policy and reasonableness can be relevant to whether a limit is reasonably and demonstrably justified under s 5 . Andrew and Petra Butler outline an approach called 'ad hoc balancing' which relies on s 5 and is in stark contrast with definitional balancing, as it requires rights to be broadly defined and all questions as to limitations and reasonableness to be left to the s 5 analysis. ${ }^{90}$

The two extreme ends of the spectrum, definitional balancing and ad hoc balancing, involve either all or no policy considerations to be discussed when the right is defined. However, as Paul Rishworth states, "the line between defining rights and considering justified limitations on them is not so easy to draw". ${ }^{91}$ In reality there are more nuanced approaches available and the appropriateness of a limitation depends on the particular nature of the right and what it is intended to protect. For example, some rights may contain definitional issues that require resolution at an early stage of interpretation, ${ }^{92}$ or, rights like the right against double jeopardy may seem so absolute that any discussion of s 5 (and possible limitations on the right) would be inappropriate. ${ }^{93}$

There are two main instances in which the nature of a right may lead to limits being read in to its definition. ${ }^{94}$ Firstly, the right may contain an internal qualifier - a word that by its nature requires definition. ${ }^{95} \mathrm{~A}$ second and more complex instance is when "considerations of purpose may lead to the conclusion that certain conduct properly falls outside the scope of

\footnotetext{
${ }^{90}$ Butler and Butler, above n 29, at 6.6.1.

${ }^{91}$ Paul Rishworth "How to Interpret and Apply the Bill of Rights" (paper presented to the New Zealand Law Society The Bill of Rights - Getting the Basics Right Seminar, November 2001) at 12.

${ }^{92}$ At 14.

93 At 14. See also the New Zealand Bill of Rights Act, s 26.

${ }^{94}$ Rishworth and others, above n 26, at 52.

95 At 52.
} 
a right and is not protected at all”. ${ }^{96}$ This may be because the conduct is beneficial in some way, or because consideration of the right's purpose demonstrates that certain conduct falls outside its scope..$^{97}$

Another relevant consideration is that interpreting rights broadly can lead to situations which may be either beneficial for society or quite trivial, needing to be justified pursuant to s 5 . This places a costly burden, ${ }^{98}$ usually on the Crown, ${ }^{99}$ which has to prove both that the action is prescribed by law and that it is demonstrably justified in a free and democratic society. Of course, the need for protection of rights means that this alone is not enough reason to conclude that all rights should be limited. However, it does mean the purpose of a right should be considered carefully in relation to the facts of a particular case, and that a right should be limited if a wide interpretation would lead to trivial or overwhelmingly beneficial actions needing to be justified under s 5 .

Overall, BORA interpretation should follow a purposive approach, which involves identifying the purpose of the right and using that to determine its scope. This can indicate whether or not a right should be limited at an early stage of reasoning. As noted by Rishworth, ${ }^{100}$ the New Zealand courts have endorsed the purposive approach, ${ }^{101}$ and are likely to follow something similar to this Canadian approach: ${ }^{102}$

The meaning of a right or freedom ... [must] be understood ... in the light of the interests it was meant to protect. ... The interpretation should be a generous rather than a legalistic one ... [but, at] the same time, it is important not to overshoot the actual purpose of the right or freedom in question.

\section{$3 \quad$ Section 11}

Section 11 does not contain an internal qualifier, as it contains no word that by its nature requires evaluation. A more pertinent issue is that of whether public health measures do or

\footnotetext{
${ }^{96}$ Rishworth, above $\mathrm{n} 91$, at 12 .

${ }^{97}$ For an example, see the debate around the right to be free from discrimination: Rishworth and others, above n 26, at 375-376; and Butler and Butler, above n 29, at 17.9.8.

${ }^{98}$ Sir Ivor Richardson "Rights Jurisprudence - Justice for All?” in Phillip A Joseph (ed) Essays on the Constitution (Brookers, Wellington, 1995) at 81.

${ }^{99}$ Rishworth and others, above n 26, at 174.

${ }^{100}$ Rishworth, above n 91, at 10.

${ }^{101}$ Rishworth and others, above n26, at 43. See also Minister of Transport $v$ Noort [1992] 3 NZLR 260 (CA) per Cooke P at 268-9, Richardson J at 277 and Hardie Boys J at 286.

${ }^{102} R$ v Big M Drug Mart Ltd [1985] 1 SCR 295 at 344. See also Butler and Butler, above n 29, at 4.2.1.
} 
should fall outside the ambit of s 11. Hansen J concluded that public health measures should fall outside s 11 , leading to the ruling that fluoridation does not constitute a breach of s $11 .{ }^{103}$ However, examination of the purpose of s 11 reveals that the scope of the right should not have been limited.

Rishworth describes rights as "labels for entitlements that we regard as generated by a set of reasons that are sufficient to justify placing other persons under a duty to respect that right”. ${ }^{104}$ In order to understand the entitlement created by s 11, the justifying reasons behind the right must be considered.

The BORA White Paper indicates that s 11 was intended to give independence in regard to medical decision making, and in doing so to: ${ }^{105}$

Permit persons to be treated against their will only where this is necessary to protect the health and safety of other persons, and not simply where their refusal of treatment will detrimentally affect their own health.

Section 11 thus protects a right to bodily autonomy, an individual's ability to have control over their body and to be able to choose what goes in to it or what is done to it. The right is a reflection of the importance placed on informed consent to medical treatment in New Zealand, a focus unique to the New Zealand setting. ${ }^{106}$ This emphasis has been influenced by the Cartwright Inquiry 1988, which found that a cervical cancer study had been conducted without the knowledge of the subjects. ${ }^{107}$ This revelation caused public outcry, due to the "lack of respect for a person's right to be informed about what other people do to their body”. ${ }^{108}$ The inquiry caused legal change, ${ }^{109}$ and attitudinal change in the form of a heightened awareness of the importance of informed consent. ${ }^{110}$

\footnotetext{
${ }^{103}$ New Health New Zealand Inc v South Taranaki District Council, above n 7, at [86].

${ }^{104}$ Rishworth, above n 91, at 8.

${ }^{105}$ Palmer, above n 31, at 109.

106 The Chief Executive of the Department of Corrections v All Means All [2014] NZHC 1433 at [46]. See also Butler and Butler, above n 29, at 11.2.3.

${ }^{107}$ Butler and Butler, above n 29, at 11.2.3.

108 At 11.2.3.

${ }^{109}$ Joanna Manning and Ron Paterson “New Zealand’s Code of Patients’ Rights” in Joanna Manning (ed)

The Cartwright Papers: Essays on the Cervical Cancer Inquiry 1987-88 (Bridget Williams Books Ltd, Wellington, 2009) 150 at 151 and 160.

${ }^{110}$ Sandra Coney "Unfinished Business: The Cartwright Report Five Years On” in S Coney (ed) Unfinished Business, What Happened to the Cartwright Report? (Women’s Health Action, Auckland, 1993) 45 at 48.
} 
The importance of control over one's body is also exemplified by the fact that there needs to be no particular reason behind refusal of treatment. An ability to refuse is itself sufficient, and is what society values. Therefore, as emphasised by Rishworth, "religious based refusals need no special privilege because competent adults may refuse for any reason”. ${ }^{111}$ Section 11 and broader overseas provisions enable an individual to determine and prioritise any considerations which they may regard as more important than the preservation of their own health. ${ }^{112}$ Further, s 11 is able to be exercised in regard to treatments of varying degrees of seriousness. As stated by Potter $\mathrm{J}$ in $M v$ Attorney General: ${ }^{113}$

A right to determine what shall be done with one's own body can be seen as important in relation to a medical examination or assessment as in respect of an anaesthetic, a surgical operation, or the administration of medicine.

The intentions expressed in the White Paper have been realised in New Zealand case law. In $R v B$, Richardson $\mathrm{J}$ stated that “On any view freedom from invasion of physical privacy and bodily integrity is a fundamental human right." 114 In doing so, his Honour confirmed that $\mathrm{s} 11$ protects bodily integrity, and identified that $\mathrm{s} 11$ is an encapsulation of a value that runs throughout New Zealand law. ${ }^{115}$ A similar discussion arose in $K R v M R$, when Miller $\mathrm{J}$ acknowledged that bodily integrity is protected by both s 11 and by the Code of Health and Disability Services Consumers’ Rights. ${ }^{116}$

The unique New Zealand context has produced a narrowly stated right which intends to protect individual autonomy in regard to medical decisions. Fluoridation is in conflict with this purpose, and should therefore be included within the scope of medical treatment.

In New Health, the Court neglected to identify the conflict between fluoridation and the purpose of s 11. Instead, Hansen $\mathrm{J}$ found that fluoridation did not constitute medical

${ }^{111}$ Rishworth and others, above n 26, at 260.

112 Elizabeth Wicks “The Right to Refuse Medical Treatment under the European Convention on Human Rights” (2001) 9 Med Law Rev 17 at 17.

${ }^{113} M v$ Attorney General, above $\mathrm{n}$ 30, at [107].

${ }^{114} R \vee B$, above $\mathrm{n} 89$, at 182 .

${ }^{115}$ At 182.

${ }^{116} K R v M R$ [2004] 2 NZLR 847 (HC) at [74]. 
treatment, a finding largely based on concerns about the potential right of an individual to veto public health measures like fluoridation. ${ }^{117}$

Public health measures which are impractical to refuse (like fluoridation) are so clearly at odds with s 11 that it is logical, if not imperative, for the state to have to justify their implementation. An inability to refuse such measures takes away an element of dignity from citizens and limits their bodily integrity by preventing them from exercising choice in regard to their bodies. The clash between these measures and the purpose of s 11 means that such measures should not be excluded from the scope of s 11. Instead, they should have to be justified under s 5 in order to be legal. As mentioned, the White Paper indicated that $\mathrm{s} 11$ is intended to "permit persons to be treated against their will only where this is necessary to protect the health and safety of other persons”. ${ }^{118}$ A s 5 analysis would require justification of public health measures and would evaluate their validity and necessity, meaning that only reasonable measures could infringe on s 11 .

The fact that s 11 is a narrowly stated right lends further support to requiring s 5 justification for fluoridation and similar public health measures. Broadly framed rights, like freedom of expression, are more likely to require limits as their already wide scope creates a higher chance for trivial issues to lead to prima facie breaches, or for activities which are clearly outside the scope of the purpose to be covered by the broad wording of the right. ${ }^{119}$ The narrowness of s 11 means that its purpose is particularly clear; it protects a specific right relating to bodily autonomy, rather than a broad right to liberty. Such a specific intention should not be ignored or limited without good reason.

\section{$4 \quad$ A Preferable Approach}

A preferable approach would be for s 11 to be interpreted broadly to include any medical treatment that has a therapeutic purpose. ${ }^{120}$ If this were the case, fluoridation would be a prima facie breach of the right and would have to be justified under s 5 .

\footnotetext{
${ }^{117}$ New Health New Zealand Inc v South Taranaki District Council, above n 7, at [87].

118 Palmer, above n 31, at 109. For a similar approach in an international context, see Douglas W Cross and Robert J Carton "Fluoridation: A Violation of Medical Ethics and Human Rights” (2003) 9 Int J Occup Environ Health 24 at 25.

${ }^{119}$ Rishworth, above n 91, at 13.

${ }^{120}$ See Butler and Butler, above n 29, at 11.8.5.
} 
The stages of reasoning likely to be followed when conducting a s 5 analysis are those set out by Tipping $\mathrm{J}$ in Hansen $v R^{{ }^{121}}$

(a) Does the limiting measure serve a purpose sufficiently important to justify curtailment of the right or freedom?

(b) (i) is the limiting measure rationally connected with its purpose?

(ii) does the limiting measure impair the right or freedom no more than is reasonably necessary for sufficient achievement of its purpose?

(iii) is the limit in due proportion to the importance of the objective

These steps were followed by Hansen $\mathrm{J}$ in New Health. His Honour concluded that if fluoridation did engage the s 11 right, fluoridation is prescribed by law and would be a demonstrably justified breach of s 11 pursuant to s 5 of BORA. ${ }^{122}$ However, this discussion was brief and not decisive, as Hansen $\mathrm{J}$ had already concluded that fluoridation is not medical treatment.

A s 5 analysis should encompass policy considerations like those discussed by Hansen $\mathrm{J}$ regarding the scope of medical treatment. For example, the need to limit an individual's ability to veto a measure that is beneficial for others would be relevant, as that would relate to whether the limiting measure impairs the right or freedom no more than is reasonably necessary for sufficient achievement of its purpose. It could be argued that fluoridation would be a reasonable limitation on the right of a small number of individuals who wished to refuse to the treatment, because of the overall benefit that it would provide for the community.

While this approach would lead to discussion of the same policy concerns raised in New Health, it is preferable because it is more likely to give effect to the purpose of BORA, which is to protect individuals from abuse of power by the state and to "provide a minimum set of standards to which public decision making must conform." ${ }^{123}$ Limiting the scope of rights means that rights are less likely to be engaged, and that the s 5 analysis is therefore

${ }^{121}$ Hansen v R [2007] NZSC 58, [2007] 3 NZLR 1 at [104], per Elias CJ at [42], per Blanchard J at [64], per McGrath J at [203], and per Anderson J at [272]. See also New Health New Zealand Inc v South Taranaki District Council, above n 7, at [101].

${ }^{122}$ New Health New Zealand Inc v South Taranaki District Council, above n 7, at [96].

${ }^{123}$ Palmer, above n 31, at 5. 
also less likely to be engaged. In the case of public health measures, it seems logical that the state should be required to prove, on the balance of probabilities, ${ }^{124}$ the reasonableness and proportionality of a measure, rather than public health measures being excluded from the scope of s 11. If a measure could not be justified under s 5, citizens would then be able to assert their s 11 right to stop it from being implemented. This approach would add to the beneficial creation of what Andrew Butler, crediting late South African scholar Etienne Mureinik refers to as a culture of justification. ${ }^{125}$ In such a culture, “citizens are entitled to call upon the provision of reasons for measures that affect their rights" and, "are entitled to expect that in advance of impairment thought will have been given to the reasonableness of a particular limit”. ${ }^{126}$ If public health measures do not have to be justified, there is less of an incentive for the state to investigate their reasonableness, and no option for citizens to question that reasonableness or the necessity of the measure under BORA.

A possible counter to above arguments is the fact that the courts have already read in a limit on the s 11 right, as only those who are competent to understand the nature of the medical treatment relevant to them can make decisions regarding refusal and consent. ${ }^{127}$ However, that limitation is acceptable as the need to read in a limit on the word "everyone" in s 11 was clear and in accordance with the purpose of the section. This limit was specifically anticipated in the White Paper, ${ }^{128}$ and before s 11 was enacted, a body of law already existed about who could refuse or give consent to treatment. ${ }^{129}$ This makes it more likely that such a limit was expected. Further, the medical law that s 11 is closely connected to focuses on the ability to give informed consent. ${ }^{130}$ Consent is only valued when a person has the capacity to understand the nature of the treatment relevant to them, and to make a decision based on that understanding. ${ }^{131}$ This was reinforced in Smith v Attorney General, where it was acknowledged that informed consent is the type of consent relevant to this type of

\footnotetext{
${ }^{124}$ See Rishworth and others, above n 26, at 174.

125 Andrew S Butler “Limiting Rights” (2003) 33 VUWLR 33537 at 554.

${ }^{126}$ At 554.

${ }^{127}$ Butler and Butler, above n 29, at 11.9.9. See for example Re E, above n 32. See also on this, Graeme Austin "Righting a Child’s Right to Refuse Medical Treatment: Section 11 of the New Zealand Bill of Rights Act and the Gillick Competent Child” (1992) 7 Otago L Rev 578.

${ }^{128}$ Palmer, above n 31, at 109.

${ }^{129}$ At 109.

${ }^{130}$ P D G Skegg “Consent” in (eds) P D G Skegg and Ron Paterson Medical Law in New Zealand (Brookers, Wellington, 2006) at 146.

${ }^{131}$ See on this P D G Skegg “Capacity for Consent to Treatment” in Medical Law in New Zealand, above n 130 at 171.
} 
right, ${ }^{132}$ as it is the type of consent valued by society. A limit on "everyone” is therefore not in conflict with the purpose of s 11 which intends to protect refusal by those who can give informed consent. In contrast, the limit that Hansen $\mathrm{J}$ read into medical treatment is not in line with the purpose of s 11 and is not obviously justified by any other reason. In order to best protect the rights and freedoms of individuals, limitations should only be read into rights when clearly necessary.

\section{$5 \quad$ Problems with the Definition Reached}

The scope of s 11 was outlined as follows: ${ }^{133}$

Medical treatment is confined to direct interference with the body or state of mind of an individual and does not extend to public health interventions delivered to the inhabitants of a particular locality or the population at large.

There are two main parts to this definition. The first, the idea that medical treatment requires direct interference, supports the second part of the definition, the conclusion that medical treatment does not cover public health interventions. This result and the narrowed scope of s 11 have the potential to lead to problematic consequences which are not in accordance with the purpose of s 11 .

A hypothetical scenario illustrates the shortcomings of this definition. If, in response to the outbreak of a disease, antibiotics were introduced to the water supply of South Auckland, individuals would not be able make a challenge via s 11. As a public health measure, this would not be 'medical treatment', even though it would involve the exact same components as something ordinarily thought of as medical treatment. This type of measure would also be in clear conflict with the purposes of s 11 , as it would ignore the bodily autonomy of citizens and restrict their decision making power in regard to medical treatment. Further, the state would not be required to justify the public health measure under $\mathrm{s} 5$, meaning that citizens would have no guarantee that the measure was proportionate and reasonable. This

${ }^{132}$ Smith $v$ Attorney General, above n 30, at [102].

${ }^{133}$ New Health New Zealand Inc v South Taranaki District Council, above n 7, at [118]. 
seems absurd, given that such a measure would lead to a large scale violation of what $\mathrm{s} 11$ is trying to protect.

The same can be said for an issue raised in New Health's submissions, about whether medication could be introduced to the water of a prison. ${ }^{134}$ According to the definition from New Health, this action would be unchallengeable under s 11 as it would be treatment administered to a group, rather than confined to interference with the body or state of mind of an individual. The fact that large scale violations of the purposes of s 11 are not covered by the definition of the right seems backward, as surely those measures are most in need of justification.

While these hypotheticals show the concerning potential of the definition from New Health, they also emphasise the validity of the preferred approach outlined above, ${ }^{135}$ as that approach would require the state to justify the above public health measures and to prove their reasonableness.

The decision from New Health gives too much power to the state in relation to public health measures, as could permit the implementation of invasive public health measures that are not challengeable under s 11 of BORA.

\section{De Minimis}

Another concerning aspect of the decision in New Health is the way that the de minimis concept, or enquiry as to materiality, is brushed over. De minimis comes from the Latin phrase "de minimis non curat lex" which translates to mean "the law does not deal with trivial things”. ${ }^{136}$ A court may invoke this approach in order to avoid addressing trivial breaches of law. For example, in Minnesota State Board of Health v City of Brainerd, Justice MacLaughlin concluded that "while forced fluoridation does intrude on an individual's decision whether or not to ingest fluoride, the impact of this intrusion on an individual's life is negligible." 137

This concept was not thoroughly addressed in New Health. Hansen J concluded that if fluoridation were to be medical treatment, an individual would not be able to practically

\footnotetext{
${ }^{134}$ Plaintiff's Submissions for Hearing on 25 November 2013 before Rodney Hansen J at [154].

${ }^{135}$ See Part IV B 4.

${ }^{136}$ A\&C Black Dictionary of Law ( $5^{\text {th }}$ ed, A\&C Black Publishers Ltd, London, 2007) at 79.

${ }^{137}$ Minnesota State Board of Health v City of Brainerd, above n 78, at 632.
} 
refuse it. His Honour then went on to state that even if this were the case, "the intrusion into an individual's right would be minimal". ${ }^{138}$ This section of reasoning is somewhat ambiguous, as Hansen J does not label his approach as de minimis, although he does imply that fluoridation would constitute a minimal breach of $\mathrm{s} 11$. His Honour acknowledges that the "enquiry into materiality is for the purposes of determining whether the right is engaged in the first place", ${ }^{139}$ indicating that a de minimis threshold is being applied to determine whether or not s 11 is engaged. This brief discussion is inadequate, as the role of the de minimis approach in a BORA context is not straightforward.

\section{The State of the Law}

While the de minimis approach has been discussed in relation to the BORA rights of persons arrested or detained (s 23), ${ }^{140}$ and freedom from discrimination (s 19), ${ }^{141}$ it is not well established that the de minimis enquiry is a requisite part of the BORA analysis. ${ }^{142}$ Conversely, the Canadian courts have stated that the Charter does not protect trivial breaches of rights. ${ }^{143}$ An application of the de minimis concept can be seen in the Canadian case of Millership v British Colombia where it was concluded that fluoridation was a minimal intrusion into Mr Millership's right to liberty and security of the person and therefore did not constitute a prima facie breach of that right. ${ }^{144}$ The right at issue in Millership was a very broad one, ${ }^{145}$ and the application of a de minimis threshold may be a tool the Canadian system uses to limit such broad rights. The same approach is not necessarily applicable to the much narrower right protected by s 11 .

In Police v Smith and Herewini, which involved application of s 23 to the taking of blood from a drink driving subject pursuant to the Transport Act 1962, ${ }^{146}$ materiality of breach was considered important. This was discussed specifically when defining detention. ${ }^{147}$

\footnotetext{
${ }^{138}$ New Health New Zealand Inc v South Taranaki District Council, above n 7, at [95].

139 At [95].

${ }^{140}$ New Zealand Bill of Rights Act 1990, s 23.

${ }^{141}$ New Zealand Bill of Rights Act 1990, s 19.

${ }^{142}$ Police $v$ Smith and Herewini [1994] 2 NZLR 306 (CA); Ministry of Health $v$ Atkinson [2012] NZCA 184, [2012] 3NZLR 456; and Child Poverty Action Group Incorporated (CPAG) v Attorney General [2013] NZCA 402.

${ }^{143}$ Millership v British Colombia, above n 21, at [103]. See also $R$ v Jones 1986 SCC 569.

${ }^{144}$ Millership v British Colombia, above n 21, at [112].

145 The Canadian Charter of Rights and Freedoms, s 7.

${ }^{146}$ Police v Smith and Herewini, above n 142, at 319.

${ }^{147}$ At 316.
} 
Richardson J stated that “... it will be important to consider the nature, purpose, extent and duration of the constraint." 148 It was concluded that "something more than a temporary check, hindrance or intrusion on the citizen's liberty is required”. ${ }^{149}$ However, Police $v$ Herewini is not authority for the fact that an inquiry into materiality is a requisite part of BORA analysis, as the discussion in that case was limited to s 23.

A more complex examination of this topic has been carried out by the courts in regard to the right to be free from discrimination, culminating in the decision in $\mathrm{MoH} v$ Atkinson. ${ }^{150}$ In Atkinson, Ellen France J concluded that the appropriate test for discrimination should be whether different treatment "imposes a material disadvantage on the person or group differentiated against". ${ }^{151}$ This is an apt approach to apply to s 19, as while the purpose of the right is to prevent differential treatment, ${ }^{152}$ treating people differently is often benign or even beneficial, and is something governments do regularly. ${ }^{153}$ It is therefore unlikely that the right is intended cover all types of differential treatment, making it appropriate to apply a de minimis threshold. However, this reasoning cannot be universally applied to all BORA rights, as the particular nature of the right in question must be taken into account.

\section{$2 \quad$ Relevance of De Minimis to Section 11}

The applicability of the de minimis approach to s 11 should have been better scrutinised in New Health. The submissions for New Health included more detail on this issue, with the submissions on behalf of the Attorney General stating: ${ }^{154}$

Section 11 also invites the application of a de minimis threshold ... If the addition of a therapeutic or preventative compound to water were to constitute medical treatment, the effect on the individual must be more than trivial or transient before it could give rise in any meaningful sense to a right to refuse it.

\footnotetext{
148 At 316.

149 At 316.

${ }^{150}$ Ministry of Health $v$ Atkinson, above n 142.

${ }^{151}$ Ministry of Health $v$ Atkinson, above n 142, at [109], emphasis added.

152 Butler and Butler, above n 29 , at 17.4.1.

${ }^{153}$ Rishworth and others, above n 26, at 375.

${ }^{154}$ Counsel for the Attorney General's Submissions on Intervention, at [91].
} 
The Council submitted that "If the Court were to consider fluoridation is a medical treatment which cannot be refused, it is submitted that fluoridation of water is nevertheless a trivial breach of that right”, ${ }^{155}$ an approach which most closely resembles that taken by Hansen J.

In contrast, New Health submitted: ${ }^{156}$

There is no such thing as a trivial or de minimis breach of the right simply because the treatment could be considered relatively minor.

In order to determine whether a de minimis threshold should be applied to $s 11$, it is appropriate to revisit the purpose of the right. As already outlined, the purpose of s 11 is not only to protect physical integrity, but also to prevent decision making autonomy. ${ }^{157}$ Applying a de minimis threshold is not in accordance with those purposes. As New Health submitted, this would mean the right would not be engaged if someone was forced to take paracetamol. ${ }^{158}$ While the physical impacts of that are likely to be minor, it would be an action taken with disregard to the autonomy of that person and would negatively impact their bodily integrity. Application of a de minimis threshold would not acknowledge that it is the ability to refuse treatment, rather than the reasons behind refusal, that is important. ${ }^{159}$ Such a threshold would be in direct conflict with the purposes of s 11, as it would restrict the element of choice that the right intends to provide and only allow recourse in relation to treatments of a certain level of seriousness. ${ }^{160}$

This issue may be further elaborated on by the courts, as application of a de minimis threshold is likely to be especially relevant if future research into fluoride demonstrates that those who consume fluoridated water are negatively impacted. The above analysis evinces that the application of a de minimis threshold to s 11 would disregard the core purposes of the right.

\footnotetext{
155 Submissions on behalf of South Taranaki District Council, at [155].

156 Plaintiff's Submissions for Hearing on 25 November 2013 before Rodney Hansen J at [161].

${ }^{157}$ Butler and Butler, above n 29, at 11.6.1. See also Palmer, above n 31, at 109.

158 Plaintiff's Submissions for Hearing on 25 November 2013 before Rodney Hansen J at [161].

${ }^{159}$ See Part IV B 3.

${ }^{160}$ Compare with $M v$ Attorney General, above n 30, at [107].
} 


\section{Conclusion}

The decision in New Health has resulted in a definition of s 11 of BORA that gives the state greater leeway to infringe on the rights of New Zealanders, without having to justify its actions.

The definition reached was limited in a way that is not required by the wording of s 11 , and the policy reasoning used to support that definition was flawed. While a desire to allow beneficial public health measures to continue is understandable, the measure taken in New Health in response to that desire was misguided. A major hindrance to the reasoning in New Health is the structure that Hansen J followed, as it too closely resembles the reasoning in the United States cases and thus takes a stance which is out of place in the New Zealand context. This structure led to a definition that is at odds with the purpose of s 11, and which may allow the bodily integrity of groups of individuals to be violated. Further, the de minimis concept was not given enough attention and should not be applied to s 11 .

A preferable outcome would involve a definition of s 11 that included public health measures, like fluoridation. It can only be hoped that the interpretation of s 11 in New Health will be rectified, when the decision comes before the Court of Appeal. ${ }^{161}$

${ }^{161}$ New Zealand Herald "Fight to Remove Fluoride Taken to the Court of Appeal" (26 March 2014) $<$ www.nzherald.co.nz >. 


\section{Bibliography}

\section{A Internet Materials}

Douglas Cross "Water Fluoridation as Mass Medication” (7 April 2013) $<$ www.xproexperts.co.uk>.

Fluoride Action Network NZ Inc “FAQ” < http://fluoridefree.org.nz>.

Fluoride Action Network NZ Inc "Fluoridation and Heart Disease" $<$ http://fluoridefree.org.nz>.

Fluoride Action Network NZ Inc “Fluoride Free New Zealand” < http://fluoridefree.org.nz>.

Food Standards Australia and New Zealand “Iodine Fortification” (September 2012) $<$ www.foodstandards.govt.nz>.

Ministry of Health "Fluoridation” (5 February 2014) <www.health.govt.nz>.

Ministry of Health “Fluoridation History (30 August 2011) <www.health.govt.nz>.

Ministry of Health “Fluoride” (20 September 2013) <www.health.govt.nz>.

Ministry of Health “Fluoride and Health” (30 August 2011) <www.health.govt.nz>.

Ministry of Health “Folate/Folic Acid” (October 2013) <www.health.govt.nz>.

Ministry of Justice “New Zealand Bill of Rights Act 1990” <www.justice.govt.nz>.

Ministry for Primary Industries "Folic Acid Fortified Breads" (2011) $<$ www.foodsmart.govt.nz $>$.

Ministry for Primary Industries "Fortification of Bread with Folic Acid Q\&A” (October 2012) <www.foodsafety.govt.nz>.

National Influenza Specialist Group “Can I get a Free Flu Vaccine” <www.fightflu.co.nz>.

New Health NZ “News” <www.newhealth.co.nz>.

New Zealand Herald "Fight to Remove Fluoride Taken to the Court of Appeal” (26 March 2014) <www.nzherald.co.nz>.

Oxford Dictionaries "Subject” <www.oxforddictionaries.com>. 
University of Otago “Fluoridating Water Does Not Lower IQ: Otago Research” (19 May 2014) <www.otago.ac.nz>.

\section{B Journal Articles}

Graeme Austin "Righting a Child's Right to Refuse Medical Treatment: Section 11 of the New Zealand Bill of Rights Act and the Gillick Competent Child” (1992) 7 Otago L Rev 578.

Andrew S Butler “Limiting Rights” (2003) 33 VUWLR 33537.

Robert E Clark and Michael M Sophy “Fluoridation: The Courts and Opposition” (1967) 13 Wayne Law Rev 338.

Douglas W Cross and Robert J Carton "Fluoridation: A Violation of Medical Ethics and Human Rights” (2003) 9 Int J Occup Environ Health 24.

Dean G Farrer “Fluoridation: Compulsory Medication of Municipal Water Supplies” (1953) 5 Urb Law 504.

Eugene Garfield "Fluoridation, 'Texas Teeth', and the Great Conspiracy” (1986) 9 Essays of An Information Scientist 3.

Phillipe Grandjean and Phillip Landrigan "Neurobehavioural effects of developmental toxicity” (2014) 13 The Lancet Neurology 330.

Brian W Head “The Fluoridation Controversy in Victoria: Public Policy and Group Politics (1978) 37 AJPA 257.

Nathanael Starrenburg “Interpretive Theories in New Zealand Bill of Rights Jurisprudence” (2004) 10 Auckland U L Rev 115.

GA Strong “Liberty, Religion and Fluoridation” (1967) 8 Santa Clara Lawyer 37.

ET Treasure and others "The York Review - A Systematic Review of Public Water Fluoridation: A Commentary” (2002) 192 British Dental Journal 495.

Elizabeth Wicks “The Right to Refuse Medical Treatment Under the European Convention on Human Rights” (2001) 9 Med L Rev 17. 
Abel Wolman, JC Geiger and WC Morse "Should Public Water Supplies be used for Mass Medication” (1947) 39 American Water Works Association 834.

Jill Wrapson "Artificial Fluoridation of Public Water Supplies in New Zealand: Magic Bullet, Rat Poison, or Communist Plot?” (2005) 7 Health and History 17.

\section{Reports}

Matthew Bradley and others A Systematic Review of Public Water Fluoridation (NHS Centre for Reviews and Dissemination, Report 18, September 2000).

New Zealand Human Rights Commission Report on Representations on Fluoridation of Water Supplies (1980).

Office of the Prime Minister's Chief Science Advisor and The Royal Society of New Zealand Health Effects of Water Fluoridation: A Review of the Scientific Evidence (August 2014).

\section{Conference Papers}

Paul Rishworth “How to Interpret and Apply the Bill of Rights” (paper presented to the New Zealand Law Society The Bill of Rights - Getting the Basics Right Seminar, November 2001).

\section{E Legislation}

\section{$1 \quad$ New Zealand}

New Zealand Bill of Rights Act ss 5, 8, 9, 10, 11, 19, 23 and 26.

\section{Other Jurisdictions}

Canadian Charter of Rights and Freedoms, s 7.

European Convention on Human Rights, art 8. 
Florida Constitution, art 1 s 23.

Irish Constitution, art 40.3.

\section{F Parliamentary Materials}

Geoffrey Palmer “A Bill of Rights for New Zealand: A White Paper” [1984-1985] 1 AJHR A6.

\section{G Texts}

George J Annas and Michael A Grodin (eds) The Nazi Doctors and the Nuremburg Code; Human Rights in Human Experimentation (Oxford University Press, New York, 1992).

A\&C Black Dictionary of Law (5 $5^{\text {th }}$ ed, A\&C Black Publishers Ltd, London, 2007).

A Butler and P Butler The New Zealand Bill of Rights Act: A Commentary (LexisNexis, Wellington, 2005).

Sandra Coney (ed) Unfinished Business, What Happened to the Cartwright Report? (Women's Health Action, Auckland, 1993).

Phillip A Joseph (ed) Essays on the Constitution (Brookers, Wellington, 1995).

Joanna Manning (ed) The Cartwright Papers: Essays on the Cervical Cancer Inquiry 198788 (Bridget William’s Books Ltd, Wellington, 2009).

Manfred Nowak UN Covenant on Civil and Political Rights: CCPR Commentary (2 ${ }^{\text {nd }}$ ed NP Engel Publishing, Kehl, 2005).

Paul Rishworth and others The New Zealand Bill of Rights (Oxford University Press, Melbourne, 2003).

P D G Skegg and Ron Paterson (eds) Medical Law in New Zealand (Brookers, Wellington, 2006). 


\section{H Case Law}

\section{$1 \quad$ New Zealand}

Child Poverty Action Group Incorporated (CPAG) v Attorney General [2013] NZCA 402.

Hansen v R [2007] NZSC 58, [2007] 3 NZLR 1.

Jeffcoat $v$ Waetford (1999) 5 HRNZ.

KR v MR [2004] 2 NZLR 847 (HC).

M v Attorney General [2006] NZFLR 181; (2005) 25 FRNZ 137 (HC).

Minister of Transport v Noort [1992] 3 NZLR 260 (CA).

Ministry of Health v Atkinson [2012] NZCA 184, [2012] 3 NZLR 456.

Moonen v Film and Literature Board of Review [2000] 2 NZLR 9 (CA).

New Health New Zealand Inc v South Taranaki District Council [2014] NZHC 395.

Police v Smith and Herewini [1994] 2 NZLR 306 (CA).

Quilter v Attorney General [1997] 1 NZLR 523 (CA).

$R \vee B$ [1995] 2 NZLR 172 (CA).

$R v$ Jeffries [1994] 1 NZLR 290.

Re E (a minor) [1993] FLR 386.

Re S [1992] 1 NZLR 363 (HC).

Re J (An Infant) B and B v Director-General of Social Welfare [1996] 2 NZLR 134 (CA).

Smith v Attorney General HC Wellington CIV 2005-485-1785, 9 July 2008.

The Chief Executive of the Department of Corrections v All Means All [2014] NZHC 1433.

\section{$2 \quad$ Canada}

Locke v Calgary [1993] 147 AR 367 (AQB).

Millership v British Columbia [2003] BCSC 82. 
R v Big M Drug Mart Ltd [1985] 1 SCR 295.

$R v$ Jones 1986 SCC 569.

$R v$ Morgentaler [1988] 1 SCR 30.

$3 \quad$ US

Dowell v City of Tulsa 273 P2d 859 (1954).

Jacobson v Commonwealth of Massachusetts 197 US 11, 25 S Ct 358 (1905).

Kraus v City of Cleveland 127 NE 2d 779 (1955).

Minnesota State Board of Health v City of Brainerd 241 NW 2d 164 (1976).

Quiles v City of Boynton Beach 802 So 2d 397 (Fla Dist App 4 ${ }^{\text {th }}$ 2001).

\section{Submissions}

Submissions on behalf of South Taranaki District Council.

Counsel for the Attorney General’s Submissions on Intervention.

Plaintiff's Submissions for Hearing on 25 November 2013 before Rodney Hansen J.

All submissions are available at New Health New Zealand Inc "Fluoride Litigation” (2014) $<$ www.newhealth.co.nz>.

\section{J Treaties}

International Covenant on Civil and Political Rights, 999 UNTS 171 (opened for signature 16 December, entered into force 23 March 1976).

\section{Word count}

The text of this paper (excluding table of contents, footnotes, and bibliography) comprises approximately 8000 words. 